\title{
A Comparison of Color and Strength Properties of Various Paper Printed with Inkjet System Using Natural Inks
}

\author{
Ahsen Ezel Bildik Dal ${ }^{*}$ \\ Istanbul University-Cerrahpasa, Forest Faculty, Forest Products Chemistry and Technology, \\ *ahsenezel.bildik@istanbul.edu.tr \\ Received: 25 November 2018 \\ Accepted: 12 February 2019 \\ DOI: $10.18466 /$ cbayarfbe.487415
}

\begin{abstract}
Printing with natural inks to the paper essential for various area like wrapping paper for foodstuff, paper cups etc. Therefore, the development of stable and commercial natural ink is gaining importance. The production methods and the surfaces chemicals (coating materials, fluorochemicals, sizing materials etc.) of the paper affect the color of the natural inks, which applied paper surface. The aim of this study is to evaluate the effect of natural inks on various paper types. Ink samples are cyan, magenta, yellow, black colors prepared to have the closest color properties to the commercial inkjet printing inks in the market. Yellow Curcuma longa extract, red Rosa canina extract, cyan Indigofera tinctoria extract, black Alkanna tinctora extract selected to prepare natural ink. The differences between the commercial ink and the natural ink applied paper samples CIE $\mathrm{L}^{*} \mathrm{a}^{*} \mathrm{~b}^{*}$ color values were evaluated. The application made with a commercial inkjet printer. Then strength properties of paper samples evaluated and compared. According to results, bleached white chemical paper color results were closest to commercial ink.
\end{abstract}

Keywords: Natural printing ink, paper color.

\section{Introduction}

The utilization of natural dyes derived from plant sources dates back to historical times. However, after the discovery of synthetic dyes, natural materials could not afford mass-scale industrial production rates and began to be reduced. As a result, most of the pigments and dyes are produced by synthetic compounds until recently [1]. However, environmental regulations have limited some of the synthetic materials in the industry and natural dyes, pigments and inks have gaining importance nowadays.

Recent development of natural digital printing inks leads to the development of biodegradable, non-toxic, environmentally friendly products. Besides, in a recycle process of the paper, natural inks are providing a cleaner ink removal system. Natural organic printing ink and paints are gaining popularity, especially for papers in contact with foodstuff [2]. It is expected to increase the demand for this kind of product [3].

Digital printing systems and conventional printing systems such as offset, gravure, flexo take their place in the printing industry in terms of both printing speed and personalized printing [4]. The rapid development of digital printing technologies allows the use of natural printing inks for trade.

Printing inks from natural substances that obtained renewable resources have some advantages. Compared the synthetic inks, natural inks do not lead environmental pollution by means of volatile organic compounds in solvents [5] besides they do not have carcinogenic or toxic features. However, natural inks $\mathrm{pH}$ and heat sensitivity, low light fastness features and vulnerability to degradation are impractical $[6,7,8]$. Besides, natural inks prone to react with paper additives such as fillers, binders, bleaching chemicals. Even production method of cellulose may even cause color differences among paper $[9,10]$. Therefore, experiments were carried out with various paper types. Paper properties effects the printing quality $[11,12]$. Thus, there is a need for a comparison of paper properties of printed samples. In this research, bleached chemical paper (BCP), mechanical paper (MP) and surface treatment with calcium carbonate paper samples (CCP) were compared according to their color properties and strength properties.

\section{Materials and Methods}

Cyan (C), magenta (M), yellow (Y) and black (K) colors were tried to be obtained from Indigofera tinctoria L., Rosa canina, Curcuma longa, Alkanna tinctora plant extracts respectively. Each application was prepared with100 $\mathrm{g}$ of dried plant sample.

The extraction of natural substances was made with a hot water bath carried out at $60^{\circ} \mathrm{C}$ for $12 \mathrm{~h}$. As a mordant $1 \%$ (w/w) Arabic gum and for conductivity and stability of the material $1 \%(\mathrm{w} / \mathrm{w}) \mathrm{Na}_{2} \mathrm{SO}_{4}$ were added to the samples whenever samples cooled $25{ }^{\circ} \mathrm{C}$ room 
temperature. Maximum dry matter of the samples was 17 $\%$ (w/w). Distilled water was used in all processes.

Surface treatment with calcium carbonate paper samples (CP), paper made from mechanical pulp (VP) and paper made from bleached chemical pulp (PB) selected for printing application.

Commercial ink an ink from plant samples were applied to these paper and CIE $\mathrm{L}^{*} \mathrm{a}^{*} \mathrm{~b}^{*}$. color measurements were evaluated with the Elrepho (Code 70, Type 991286, No 8803564). Paper surface were printed with commercial and natural ink samples using a commercial printer.

\section{Results and Discussion}

All paper samples were conditioned prior and after printing application at $23{ }^{\circ} \mathrm{C}$ and $50 \%$ relative humidity for 24 hours according to ISO 287. Color values and strength properties performed in İstanbul UniversityCerrahpasa, The Forest Product Chemistry and Technology Laboratory. Color values performed under $10^{\circ}$ observer and a D65 light source CIE L * a * b * color results of printed paper were given in Table 1 . In the table, ' $\mathrm{X}$ ' represented extracted ink samples, ' $\mathrm{O}$ ' represented commercial ink samples. Cyan, Magenta, Yellow and $\mathrm{K}$ (Black) are represented as their capital letter.

Table 1. CIE L * a * b Color Results of Paper Samples.

\begin{tabular}{ccccc}
\hline $\begin{array}{c}\text { Color } \\
\text { Code }\end{array}$ & $\mathbf{L}^{*}$ & $\mathbf{a}^{*}$ & $\mathbf{b}^{*}$ & Chroma \\
\hline CP & 93.20 & 2.74 & 8.16 & - \\
VP & 98.11 & 1.78 & -2.09 & - \\
PB & 94.25 & -0.46 & 6.10 & - \\
\hline XYCP & 90.27 & 0.62 & 39.74 & 14.81 \\
XYVP & 98.35 & -2.53 & 16.13 & 15.31 \\
XYPB & 93.64 & -3.42 & 16.78 & 20.26 \\
\hline XMCP & 76.65 & 7.01 & 3.86 & 18.41 \\
XMVP & 86.22 & 3.59 & -2.15 & 13.06 \\
XMPB & 85.19 & 9.21 & 5.48 & 11.17 \\
\hline XCCP & 64.97 & -6.29 & -8.30 & 9.57 \\
XCVP & 88.71 & -3.58 & -8.57 & 9.25 \\
XCPB & 86.17 & -5.46 & -4.16 & 8.61 \\
\hline XKCP & 74.10 & 2.01 & 14.21 & 14.90 \\
XKVP & 84.31 & 1.78 & 15.18 & 16.09 \\
XKPB & 80.02 & 1.25 & 17.31 & 17.31 \\
\hline OYCP & 77.83 & 16.41 & 0.36 & 19.03 \\
OYVP & 85.29 & 14.31 & 0.28 & 14.98 \\
OYPB & 81.14 & 14.21 & 0.31 & 14.78 \\
\hline OMCP & 43.38 & 41.31 & -18.13 & 43.91 \\
OMVP & 49.12 & 42.25 & -16.34 & 45.55 \\
OMPB & 40.77 & 45.39 & -14.21 & 47.56 \\
\hline OCCP & 47.33 & -23.72 & -29.25 & 39.36 \\
OCVP & 50.25 & -26.01 & -31.41 & 41.54 \\
OCPB & 51.54 & -30.65 & -29.16 & 42.03 \\
\hline OBCP & 31.05 & 0.38 & 1.05 & 1.21 \\
OBVP & 34.46 & 0.89 & 1.19 & 1.98 \\
OBPB & 31.32 & 1.07 & 3.02 & 2.71 \\
\hline & & & & \\
\hline
\end{tabular}

Base paper samples properties were given in Table 2.

Table 2. Base Paper Properties.

\begin{tabular}{ccccc}
\hline $\begin{array}{c}\text { Color } \\
\text { Code }\end{array}$ & $\begin{array}{c}\text { Basis } \\
\text { Weight } \\
\left(\mathbf{g} / \mathbf{m}^{\mathbf{2}}\right)\end{array}$ & $\begin{array}{c}\text { Burst } \\
\text { Index } \\
(\mathbf{k P a} * \\
\left.\mathbf{m}^{2} / \mathbf{g}\right)\end{array}$ & $\begin{array}{c}\text { Tensile } \\
\text { Index } \\
\mathbf{M . D .} \\
(\mathbf{N m} / \mathbf{g})\end{array}$ & $\begin{array}{c}\text { Elongation } \\
(\mathbf{\%})\end{array}$ \\
\hline $\mathrm{CP}$ & 60.64 & 4.46 & 37.53 & 1.26 \\
$\mathrm{VP}$ & 61.24 & 5.38 & 45.59 & 1.68 \\
$\mathrm{~PB}$ & 59.92 & 4.94 & 43.74 & 1.92 \\
\hline
\end{tabular}

The results of basis weight and strength properties of ink applied paper samples were given in Table 3. Tensile index test was made machine direction (M. D.) of the samples due to paper position in the printing application. Extracted sample results were higher than commercial ink. The differences between results were due to increased viscosity of the extracted samples. Extracted ink applied samples strength results were decreased more than commercial ink applied samples (Table 3). Due to the acidic nature of natural ink, inter - fiber bonding was more damaged than commercial ink

The biggest obstacle of the application was buffer could not be used because of $\mathrm{pH}$ sensitivity of natural inks.

Table 3. Basis Weight of Ink Applied Paper Samples.

\begin{tabular}{|c|c|c|c|c|}
\hline $\begin{array}{l}\text { Color } \\
\text { Code }\end{array}$ & $\begin{array}{c}\text { Basis } \\
\text { weight } \\
\left(\mathrm{g} / \mathbf{m}^{2}\right)\end{array}$ & $\begin{array}{l}\text { Burst } \\
\text { Index } \\
(\mathbf{k P a} * \\
\left.\mathbf{m}^{2} / \mathbf{g}\right)\end{array}$ & $\begin{array}{l}\text { Tensile } \\
\text { Index } \\
\text { M.D. } \\
\text { (Nm/g) }\end{array}$ & $\begin{array}{c}\text { Elongation } \\
(\%)\end{array}$ \\
\hline $\mathrm{XYCP}$ & 61.12 & 4.35 & 30.26 & 1.02 \\
\hline XYVP & 62.36 & 5.21 & 42.21 & 1.28 \\
\hline XYРB & 60.06 & 4.56 & 40.14 & 1.36 \\
\hline XMCP & 61.14 & 4.34 & 34.21 & 1.01 \\
\hline XMVP & 62.33 & 5.14 & 43.28 & 1.21 \\
\hline XМРB & 60.09 & 4.31 & 38.96 & 1.39 \\
\hline $\mathrm{XCCP}$ & 61.11 & 4.37 & 31.21 & 1.03 \\
\hline XCVP & 62.37 & 5.20 & 43.14 & 1.11 \\
\hline ХСРB & 60.08 & 4.42 & 41.51 & 1.26 \\
\hline $\mathrm{XKCP}$ & 61.19 & 4.40 & 33.31 & 0.98 \\
\hline XKVP & 62.31 & 5.18 & 40.16 & 1.09 \\
\hline XКРB & 60.02 & 4.01 & 39.74 & 1.14 \\
\hline OYCP & 60.68 & 4.45 & 29.26 & 1.15 \\
\hline OYVP & 61.29 & 5.00 & 40.21 & 1.21 \\
\hline OYPB & 59.96 & 3.98 & 40.44 & 1.38 \\
\hline OMCP & 60.67 & 4.40 & 23.35 & 1.10 \\
\hline OMVP & 61.28 & 4.98 & 41.81 & 1.36 \\
\hline OMPB & 60.01 & 4.46 & 40.16 & 1.54 \\
\hline OCCP & 60.70 & 4.41 & 29.21 & 1.09 \\
\hline OCVP & 61.32 & 5.06 & 41.51 & 1.20 \\
\hline OCPB & 59.99 & 4.31 & 40.18 & 1.51 \\
\hline OBCP & 60.69 & 4.34 & 34.15 & 1.13 \\
\hline OBVP & 61.31 & 5,12 & 40.28 & 1.37 \\
\hline OBPB & 59.98 & 4.52 & 41.02 & 1.42 \\
\hline
\end{tabular}

After extracted ink application, paper samples photo was given in Figure 1. According to color results in Table 1 
and Figure 1. mechanical pulp samples (VP) had lower results comparing to commercial ink due to lignin and hemicelluloses content of their structure.

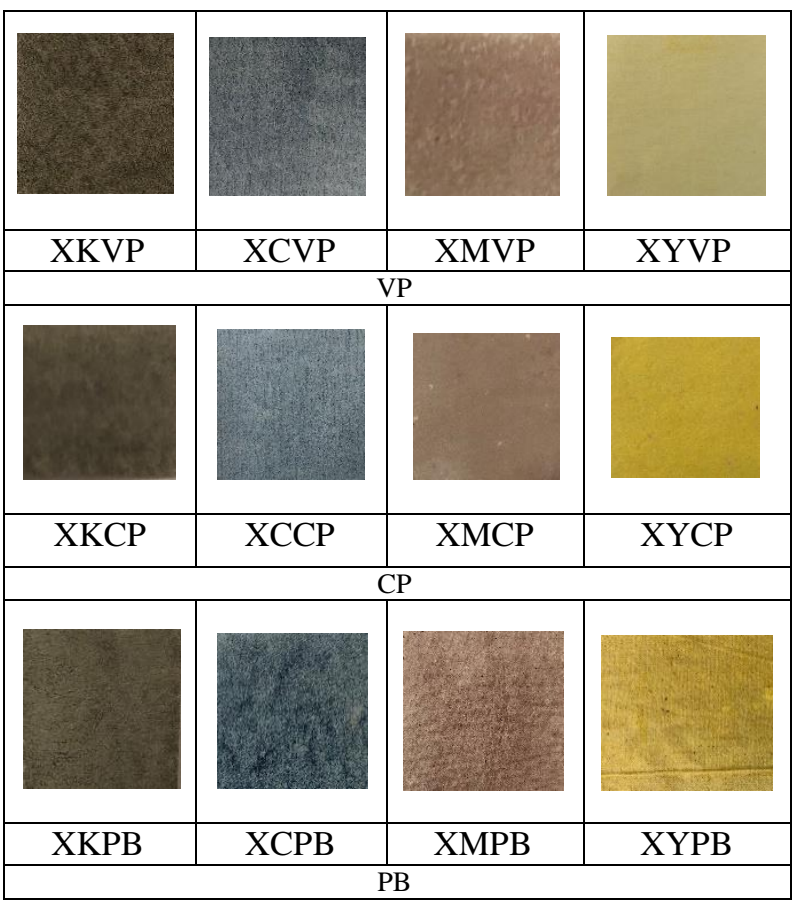

Figure1. Natural Ink Applied of Paper Samples.

\section{Conclusion}

The potential utilization of four main color of natural inks were examined and appropriate formulation improved. The commercial inks CIE $\mathrm{L}^{*} \mathrm{a}^{*} \mathrm{~b}^{*}$ values were compared to the natural inks. According to analysis of the color properties of the inks, it was obvious that magenta color values need to be improved with various additives. Especially Rosa canina extracts reacted with calcium carbonate surface coating material and gave purplish color results. Also paper made by mechanical pulp sample gave similar result. A possible cause of purplish color is the presence of hemicellulose and lignin in mechanical paper. The results indicate that the color results of natural ink and commercial ink were dependent on paper surface and chemical properties of the surface material.

\section{Ethics}

There are no ethical issues after the publication of this manuscript.

\section{References}

1. Gilbert, KG, Cooke, DT. 2001. Dyes from plants: Past usage, present understanding and potential. Plant Growth Regulation. $34-57$.

2. Forrest, MJ. Coatings and Inks for Food Contact Materials; Rapra Technology: UK, 2005.
3. Shahid, M, Faqeer, M. 2013. Recent advancements in natural dye applications: a review. Journal of Cleaner Production. 310-331.

4. Kipphan, H. 2001. Print Quality; Handbook of Print Media: Technologies and Production Methods, Germany, Springer, 2001, pp 68-113.

5. Porter, ME, Linde, CVD. Green and Competitive: Ending the Stalemate; The Dynamics of the Eco-efficient Economy Environmental Regulation and Competitive Advantage, UK, Edward Elgar Publishing, 2000, pp 38.

6. Crews, PC. 1982. The Influence of Mordant on the Lightfastness of Yellow Natural Dyes, Journal of the American Institute for Conservation. 21(2): 43-58.

7. Gürses, A, İkyildiz, MA, Güneş K, Gürses, MS. Dyes and Pigments: Their Structure and Properties; Dyes and Pigments, Chapter 2: Switzerland, Springer International Publishing A.G., 2016, pp 13-29.

8. Oyarzn, JM. Optical Properties of Pigmented System; Pigment Processing:Physico-Chemical Principles, Part 2, Germany, Vincentz Verlag, 2000, pp 67-68.

9. E. Huwald, E. Calcium Carbonate - Pigment and Filler, Calcium Carbonate: From the Cretaceous Period into the 21st Century, Germany, Springer Basel AG, 2001, pp 160-168.

10. Özden Ö, Sönmez, S. Pigments Used in The Coating of Paper and Cardboards, The Most Recents Studies in Science and Art, vol. 2, Ankara, Turkey, Gece Kitaplığı, 2018, pp 1979-1993.

11. Sönmez, S. 2017. Comparison of into the Effects of Ultraviolet Flexo Ink on Printability of the Paperboards Coated with Carboxymethyl Cellulose and Polyvinyl Alcohol. Journal of Polytechnic. 20(4): 985-991.

12. Yang, L. Paper, Ink-Paper Interaction, Norrköping, Sweden, Printed in Sweden by UniTryck, 2003, pp 9-19. 